\title{
A Business Model Canvas: Traditional Restaurant "Melayu" in North Sumatra, Indonesia
}

\author{
Muhammad Isa Indrawan \\ Department of Management, University of Pembangunan Pancabudi, Indonesia \\ E-mail: musawan@gmail.com
}

Muhammad Dharma Tuah Putra Nasution (Corresponding author)

Department of Management, University of Pembangunan Pancabudi, Indonesia

E-mail: dharmatuah@gmail.com

\section{Efrizal Adil}

Department of Management, University of Pembangunan Pancabudi, Indonesia

E-mail: eadillubis@gmail.com

Yossie Rossanty

Department of Management, University of Pembangunan Pancabudi, Indonesia

E-mail: yosunpab@gmail.com

Received: October 23, 2016 Accepted: October 31, 2016 Published: December 3, 2016

doi:10.5296/bms.v7i2.10193 URL: http://dx.doi.org/10.5296/bms.v7i2.10193

\begin{abstract}
The research purpose is to evaluate the business model on the traditional restaurant in Tanjung Pura, North Sumatera, Indonesia. Business Model Canvas (BMC) consists of customer segments, value propositions, channels, customer relationship, revenue streams, key resources, key activities, key partnership, and cost structure. The research method was used
\end{abstract}


qualitative descriptive analysis. The data collected using in-depth interviews. Analysis TOWS is to evaluate the business model on a traditional restaurant. The authors recommend increasing the intensity to visit the restaurant with the privilege of membership. The next recommendation is to collaborate with the new business partners such as banking, e-traveler, e-destination, and e-restaurant. The traditional restaurant enables to obtain the other revenues of the subscription fee and advertising space. Also, the authors recommend registering the food recipes as the intellectual property.

Keywords: Business Model Canvas, TOWS analysis, Traditional restaurant 


\section{Introduction}

The business model articulates logic and provides data, also another evidence that demonstrates how the company creates and delivers value to customers. The business model outlines the architecture of revenues, costs, and current profits related to the value of the company. In short, the business model was defining how the company creates and delivers value on the activities, and then converting the payment received for the current profits. The study of Teece (2010) argues that the innovation of business model enable to be reached on the competitive advantage if the business model can be differentiated, and difficult replicated by incumbents and new entrants that have a similar license.

In essence, the business model embodies nothing less than the organizational and financial architecture of the business. Teece (2010) describes that a good business model yields screened of compelling value propositions to an activity. The achievement of advantageous cost and risk structures have the significant value of the business generating and delivering of products or services. The business models have necessary features of market economies where consumer choice, transaction costs, and heterogeneity among consumers and producers as well as competition. The companies prioritize of profit in competitive environments. Its will endeavor to fulfill the consumer wants to be variegated, the invention constantly and delivering of the new value propositions against consumers. The business models filled up necessary the innovation of technology and to create the need to bring discoveries to the market, and the opportunity to satisfy unrequited customer needs (Teece, 2010). Hence, the business model is how the companies deliver value to fulfill and convert of payment into the current profits.

Focusing analysis situated on the concept of business model. The perspective of Badden, et.al, (2010) explains that how a company sets itself to create and distribute the value in a way that is profitable. The business models have a multivalent character as the models. They can find as the role of prototype models that might be copied or presented as nutshell descriptions of the business organization that was simplified. Furthermore, Badden, et.al., (2010) reveal that business person could think of them not only with capturing the characteristics recognized from classification in the world, yet it also as abstract ideal types. How the business models as models, challenges the idea and ideal of any single or fixed the taxonomy of business models. In contrast, the developing analysis of business models itself has prompted to the expansion of taxonomies and typologies. In ways which discharge the new lights on the role and nature of business models themselves. Thus, the business models function as models in the scientific sense (Badden et al. 2010).

Nowadays, the business model reveals how the business works and what nature of business value that must have the customer and how communicated and transferred to the customer. The popular business model of Osterwalder as the business model illustrates the idea of how an organization creates, delivers and capture of values (Osterwalder, 2005; Osterwalder \& Pigneur, 2010). Why the business models necessary conducted, as Morris et al. (2005) argues that required three principal reasons to show model conduct; first, the viewpoint of economic 
intended for the benefit of income source and cost structure. Both, the operational aspect is more focused on the operational architecture, configuration to create a value of design of business infrastructure; and third, view of the strategic point on, the company position, such as determine the company's market position, and also to detect the market growth opportunities.

Mitchell \& Coles (2004) argue the business model meant how the company affording the goods and services; how the company generates the resources to sustain the efforts. The business model replacement enables to improve the performance of the business. The elements of the business model to create sustained enhancements from company earnings, cash flow, and activities revenues. The business model innovation expresses that the business model replacements can provide the product or service offering to end users that were not available previously. This business model is valuable and as the company source in competitive advantages. Levy (2001) indicates that the consequence of business model which organized the company was not able to reach out maximum if it was not based on the assessment and formulation of business model appropriate. The implementation of the business model is not accurately which may affect on financial risks (loss or loss of): the opportunity and potential is outside of business; the presence of business model appropriate, and has to concern on sustainability of business. The critical point in evaluating the business model is relevant in the world of business including in the culinary field. Thus, the traditional restaurant enables to implement the appropriate business model to attract customers visiting the restaurant.

Hence, in this research, the authors identifying and evaluating a business model on the traditional restaurant as well as to recommend a new business model. This work, based on the Business Model Canvas from Osterwalder and Pigneur (2010) that consists of nine elements of Business Model Canvas divided over customer segments, value propositions, channels, customer relationship, revenue streams, key resources, key activities, key partnerships, cost structure.

\section{Literature Review}

\subsection{Customer Segments}

The various of customer segment by Ostewalder \& Pigneur (2010) that consists of (1) Mass market, which means a business has the target market for all customer segments and is not distinguished. (2) Niche market, which means a business model has a target market that only serves to the specific segment or more specific. (3) Segmented, which means a business model distinguishes of customers need and diversity of customer issues. (4) Diversified, which means the business model serves two or more to fulfill the diverse need and depend on each other. Customers are the essential point to get profit or benefit. The company is not able to sustain the business built without the customers. Osterwalder \& Pigneur (2010) also divide into both of market segments based on the need and consumer behavior from the segment such as the middle-upper class, and lower-middle class 


\subsection{Value Propositions}

Value propositions described how the customers switch to another company through the product or services offered by different companies in the business model canvas of competitors (Osterwalder \& Pigneur, 2010). The note of Osterwalder and Pigneur (2010) contributes to creating the value propositions among the others that are: (1) Newness, shows that the new product was created had never existed before, and it has the uniqueness. (2) Performance indicates, how can improve the performance of the products or services which added. (3) Customization shows how the companies may customize the products or services to fulfill the customer needs, so that acquired more value. (4) Getting the job done, how the products or services can support the customers to complete the job. (5) Design indicates how the attractiveness of design and product will have the value proposition. The design indicates complex and attractiveness was measured due to each customer has a different opinion. (6) Brand/status; customers, may find the product value of the brand recognized community. (7) Price, how the price has been determined by their competitors and became the reason to decide the price of products offered. In this case, customers could be sensitive on price offer. (8) Cost reduction, how values obtained from costs incurred by customers to purchase the products or services can reduce. (9) Risk reduction, which means the risk of product to the customers offered that is low risk. In other words, the products offered have the guarantee if the failure occurs. (10) Accessibility, product offered can be used comfortably or can be accessed for all individual. (11) Convenient or awarded which means the product can fulfill the need and wants, as well as feel comfortable with the product presence.

\subsection{Channels}

Channels which describes how the company to build the communication with customers to deliver value propositions (Osterwalder \& Pigneur, 2010). There are several objectives of the channel, consist of: (1) To increase customers awareness of products and services which company offered. (2) To encourage customer evaluation on the company's value proposition that was offered. (3) To allow the purchase of products or services more accurately. (4) To provide company's value proposition for customers. (5) To provide services of post-purchase.

\subsection{Customer Relationship}

Customer relationship formed as the customer segment, due to differing characters of each segmented. Customer relationship has the close relations through the diverse ways; "Customer Acquisition, Customer Retention, Upselling." The note of Osterwalder \& Pigneur (2010) argue that customer relationship divided into several parts: (1) Personal assistant, which means communication occurred among customers and the officer of the customer service as personal assistance during in purchase process, or post-purchase. (2) The dedicated personal assistant is to allow a person in serving to appropriate customers personally. (3) Self-services which mean customers certainly related to the company indirectly, but the companies provide to customers the facilities that required to support himself. (4) Automated service, which means the combination of the relationship between self-services processing 
related to the services of the restaurant. (5) Communities, which mean the company builds the relationships with fellow members of the community to interact the ideas so that understand the desire of the customers. (6) Co-creation, which means the company builds the relationship with customers to create the value proposition which the new one.

\subsection{Revenue Streams}

Revenue streams show how income received of each customer segment related to the value proposition which is given to the customers (Osterwalder \& Pigneur, 2010). In case, the business model has the different revenue streams among others: (1) Transaction revenues indicate the revenues obtained from each payment from the customers. (2) Recurring revenues show that revenues obtained from current payment to provide the value proposition and support the post-purchase of services.

The revenues can be achieved in several ways, as noted on Osterwalder \& Pigneur, (2010), (1) Asset sale, indicates the company has sold the assets to obtain the revenues. (2) Usage fee shows the revenues derived from many customers that use the product or service which offered by the company. When the product is much used, then the expenditure of customers may be larger. (3) Subscription fee indicates the revenues generated from continuity sales services. (4) Lending / Renting / Leasing indicates the revenues generated relating to provide the exclusive right in using the assets for the certain periods and during the renting fees paid to the asset's owner. (5) License, which means the revenues derived from the provision of intellectual rights to buy the license can use their company, so that open the similar business. (6) Brokerage fee, which means the revenue generated from intermediary services cost that derived from the large percentage previously that agreed between buyer and seller. (7) Advertising indicates the revenue obtained from the advertisement of the product, brands or services.

\subsection{Key Resources}

Key resources as the valuable asset necessary to make a business move smoothly. According to Osterwalder \& Pigneur (2010), all of the business models require resources. The main resource categorized into the types: (1) Physic, which includes buildings, machinery, land, vehicles. (2) Intellectuals, which includes intellectual property rights, patents, brand. (3) Human, in particular, human resources as an essential part of the company, creative industries, and major labor-intensive resource which is a human resource for himself. The company sought to create the conducive of atmosphere in the company to sustain the human resources. (4) Financial, which reflects the financial performance of the company or velocity of money which has happened in the company. Without supporting the stability of assets, then the business may not operate properly.

\subsection{Key Activities}

Key activities emphasize the most important that must be done by the company; to determine the business model work in creating the products and services. As noted in Osterwalder \& 
Pigneur (2010) key activities can be categorized into three parts: (1) Production, show the activities related to the design, manufacture, and on the product.(2) Troubleshooting indicates the activities related to issues arising from such products. The companies must address the problems that arise not only in the product but the company must also be able to engage the customers' request that their products may accept with the customer.(3) Platform / Network, the business model whose main activities related to the network and the majority of companies which were engaged in the technology information field.

\subsection{Key Partnership}

The company formed by the alliance or cooperate for various reasons. The company is created to optimize the business, reduce the risks, and have the high competitiveness. Osterwalder \& Pigneur (2010) argue that the partnership can classify into four classes: (1) Strategic alliance means the alliance with non-competitors. (2) Collaboration indicates the strategic partnerships with the competitors (3) Joint venture to develop new business. (4) Buyer-supplier relationships, the assure of reliable supplies. Furthermore, as a note of Osterwalder \& Pigneur (2010) there are three main motivations to build the good partnership: (1) Optimizing of economies of scale, to the allocation of resources and business activity. (2) Reduction of risk and uncertainty intend the cooperate aimed to reduce the risks in a competitive rivalry which has the uncertainty characteristics. (3) Acquisition of resources and distinct activity indicates the company has own resources and leads to the business activity following the business model.

\subsection{Cost Structure}

Cost structure indicates that all costs incurred operate on the business model. Costs can be estimated properly if the primary activity, key resources, and partnerships have been determined. Osterwalder \& Pigneur (2010) noted that the cost structure of the business model was classified into two parts: (1) Cost driven from the business model focused on reducing the costs as low as possible. It showed that the goals were to keep the cost structure, so that used the value proposition at a low price. (2) Value-driven, showed that the company was not overly concerned with the costs that would occur within the framework of the business model and more focused on the value creation. Osterwalder \& Pigneur (2010) mention that costs structure has the following characteristics: (1) Fixed costs indicate fixed costs do not change and will not affect on sales generated. (2) Variable cost shows that the cost can be improved by the goods produced. (3) Economies of scale determine the company can minimize the costs of production for producing goods in large quantities while the company was only able to produce in the small capacity of goods. (4) Economies of scope show that the cheaper cost is the advantage during the company operate becomes greater with extending the industry area both in domestic and abroad.

After identifying the nine elements of BMC on the traditional restaurant, the authors lead to the analysis of TOWS. The concept of TOWS (Threats, Opportunities, Strengths, and Weaknesses) was an approach of SWOT model. In this concept, the principle of mind that 
happen on several companies in a current position. SWOT concept emphasizes that the first point with identifying the position of the company be contemporary. Concerning the strengths and weaknesses used to predict the opportunities and threats from the positioning in the future which enable achieved or considered realistic. SWOT analysis affords the basis useful for further discussion, decision making, and finally as an innovative business model (Osterwalder \& Pigneur, 2010)

Meanwhile, the difference of TOWS concept is the first point to make the vision of the company position to determine the threats or opportunities, then to identify the business views of strengths and weaknesses. The current business conditions related to the vision and current conditions. The business vision or purpose placed in the first step which was the embodiment of a way of thinking "Starting From the End" or "End In Mind" concept, which was a way of thinking based on the nature concerning the goals as starting point for beginning the planning and the next step.The difference concept of SWOT and TOWS were not simply about how to create, but more fundamentally of the diversified paradigms. The concept of "End In Mind" leads it a way of thinking that appears not apply on ultimate experience as a way to be supported. In consequence, it must eliminate to accomplish the greater goals of the 'extrapolation' pattern. The extrapolation patterns as set goals or targets for the future by attracting the tendency based on earlier data.

\section{Research Method}

This research method is the qualitative descriptive research which pointed out the Business Model Canvas of the traditional restaurant. The evaluate of its elements used TOWS analysis. Data collected in-depth interviews from key informers about the nine elements of the Business Model Canvas. This research used purposive sampling. The key informers are selected to obtain accurate information related to the activity of the traditional restaurant. The validity of data used the triangulation technique to aim the information crosscheck among the key informers. The steps of the qualitative data analysis process starting from data reduction that indicates the data, qualifying obtained from the interview and observation. Data interview was the interface with the key informers selected as significance information. The next step is the data display in the form of a brief description that contains information approximately the business model canvas on the traditional restaurant at Tanjungpura, North Sumatera province, in Indonesia. Ultimately, as the conclusion with the comparison between the implementation of the business model canvas on the traditional restaurant with the literature in the research

\section{Result and Discussion}

\subsection{Business Model Canvas}

Business Model described using the business model canvas on Traditional restaurant. The description of the Business Model using the Business Model Canvas as follows. 


\subsubsection{Customer Segment}

At the beginning, the traditional restaurant only serves families who travelers via Tanjung Pura. Customers can enjoy the beauty of the river in Tanjung Pura, as frequent travelers are harbored and enjoy the special food cuisine Tanjung Pura. The traditional food using recipes "Melayu" that is an inheritance from their parent. Nowadays, the traditional restaurant does not only serve the travelers who harbored but already managed to attract the travelers from various regions from the outside of North Sumatra province. As declared by Osterwalder (2010), customer segment of the traditional restaurant, including in the variety of "segmented" that directed to serve the needs of their customers and solving their problem. The traditional seafood has a normal price 65,000 rupiahs per person. Seen in the consumer's willingness to pay, its price value is expensive size base on the food expense in this area.

\subsubsection{Value Proposition}

The traditional restaurant position is on the river side of "Sei Wampu." This river had a history happening on the local society. Additionally, from being the trade route, the river is one of the attractive for people in Tanjung Pura. The traditional restaurant offers the atmosphere of the restaurant which provided a natural nuance, a view of the small ships whom fishers own that require going to the sea. The condition such as the situation in the past and it will be attractive for people who come from the big city. The value proposition of the restaurant such as large crabs, shrimp, and fish caught by fishers were originated from "Sei Wampu" river and the local society declared shrimp "Galah." Indeed, an experience of the restaurant includes the value proposition offered to the customers. Moreover, a specific food taste with the original recipes of "Melayu" culture is a part of the value proposition to the customers. Although the restaurant does not have the air conditioning, the breeze made the air circulation remains fresh, and even this would be an appeal for the visitors. The newness proposition of traditional restaurant with providing the specific fish that they called "Sembilang." Similarly, the crab type that derived from mangrove forests in Tanjung Pura. Beside from the nature of seafood offered as a value proposition, the restaurant food process is also an attractive value, with using a traditional kitchen, it will add the naturalness value of the food cooking result. Moreover, in the specific spices used, it will insert the delicious food taste from this restaurant. The familiar of traditional food offered by the restaurant which they called as"Gulai Asam."Various types of traditional food "Melayu" served to satisfy the visitors, due to their desire to enjoy the food menu that could be fulfilled. The traditional restaurant has used the recipes inherited from the ancestors. These food recipes are very rarely found in the major cities, North Sumatra. Concerning in the service of the traditional restaurant may combine the food menu with the old container while accompanied by the usual Melayu music. It could be added to taste the visitors that enjoyed the food provided. The restaurant atmosphere is a full of intimacy that described a situation as the villages of origin of the visitors. 


\subsubsection{Channels}

Most of the information about the restaurant obtained from the families that recommend and relatives of the visitors which led the visitors who first came must ask the help of the community about the restaurant location. Indeed, this traditional restaurant location is not an ideally located on the main road, but the access to entry the restaurant through this main road that leads to the site. However, the condition does not make the restaurant devoid of visitors. More surprising, they were willing to queue to take place in the restaurant. The phenomenon is different from any other restaurant that located near from the traditional restaurant. The manager attitude shows the friendliness who always welcomes to their visitors at the entrance of the restaurant. This attitude has eliminated chagrin the visitors from queuing up. Similarly, the waitress treats the visitors in serving them politely and in a friendly way. Regarding information on products, and services for the restaurant, the waitress trained to increase their knowledge and experience in delivering the food menu information to the visitors. For instance, the availability of fish, crabs, and shrimp on that day due to the supply of shrimp and crab greatly depending on season and weather. Also, the waitress delivering the information related to the source of fish that caught by fishers. It indicated that the fish is the new and fresh. Furthermore, the waitress has a responsibility to offer a specific menu that would select by the visitors. Usually, the visitor's response has been very pleased, when the waitress offered the interesting menu to their eat and drink. Also, the waitress offered the fresh beverage such as green coconut drink. This condition will affect the customer's satisfaction. The restaurant has the commitment to fulfill the expectation of customers. Nevertheless, it cannot deny if there are customers complaint about the services of the restaurant. When the customers had to order the food menu, their orders often arrive too late. The condition may explain by the waitress that the cook's process was using the traditional model. For type and process of the cuisine had the different time and process. Therefore, this explanation to prove that the traditional restaurant was using the channel to deliver a value proposition still conducted directly.

\subsubsection{Customer Relationship}

The customer relationship has the goals. One of the business goals is to enlarge the market segment consistently. Osterwalder \& Pigneur (2010) describe that the business success was to establish the customer's relationship with closely and through the customer acquisition. Sustainability of the business showed that how much the efforts of the traditional restaurant to capture the new potential customers. The key informers describe that the restaurant was building the customer relationships rely on the role of the waitress to serve the visitors. The restaurant expects that the waitress has the friendly attitude to give the positive image by visitors. Hence, the customers experience to visit the traditional restaurant will be delivered to consumers who had never tried the cuisine of this restaurant

Also, the customer relationship was to maintain the relationship with the old customers. A breakthrough made only limited to demonstrated the proactive attitude and behavioral showed to the old customers when they visit again to the traditional restaurant. Nonetheless, 
Traditional restaurant manager always requests to the suggestions of the visitors. For instance, the specific menu that expected. These relations show that as a restaurant attempted to create the new proposition which ready offered to the visitors in the future or its mentioned "co-creation" by Osterwalder \& Pigneur (2010)

\subsubsection{Revenue Streams}

The next element of the Business Model Canvas is the revenue streams. The business model of traditional restaurant relies on the payment transaction process. The business transaction of the restaurant using the cash payment system and does not accept the payment from the credit card. Key informers argue that the visitors seldom inquire the payment machine facility. Moreover, the business activities of the restaurant do not earn income from the sale of assets, subscription fee, lending or leasing, license, brokerage fees, and advertising (Osterwalder \& Pigneur, 2010). The primary revenue source of the traditional restaurant obtained from the customers which food orders. Osterwalder \& Pigneur (2010) describe that the revenue obtained from some customers orders or mentioned "usage fees."

\subsubsection{Key Resources}

Key resources as the essential assets to the continuity of business sustainability. Therefore, the priority of business management necessary to increase and utilize the assets to be more productive. Key informer describes that the restaurant has the current assets and fixed assets or tangible assets. Key informer explains that the tangible assets have a lower amount than the intangible assets. The food recipes as higher value, and including intellectual asset. Confidentiality of these recipes only contributed to the next generation. Besides that, key informer recognizes that the waitress, chef, cashier and the other workers are involved in the business activities as company assets which must be maintained and developed. Human resources are the productive assets of the restaurant. These assets have the leverage to increase the value of company business. The success of the business required seriousness and the high involvements from the workers. Besides that, the traditional restaurant has not planned to rent the money in developing business from the other areas. At this time, the traditional restaurant still uses the working capital and business income from payment transactions food by customers. For a business owner, to rent the money from banks will increase the production costs, which can increase the food menu price. They suffer the customers will consequently the decrease on a visit due to the food price menu will be expensive.

\subsubsection{Key Activities}

The traditional restaurant has the main activity that started with the purchase of raw materials (such as fish, crabs, and shrimp) until delivering to the customers. The workers assigned to purchase the materials have to know the type and quality of raw materials which they purchase. Furthermore, the purchase of spices about adjusting the flavor of cuisine with the customer's expectation. Although the traditional restaurant often faces the rising prices of spices, fish, and shrimp, however the restaurant still protects the quality and flavor to build 
the positive image of the restaurant; to maintain the loyalty of visitors. The next activity started from the selection process of the raw materials, cleans, and storage. The storage goal is to keep the supply of raw materials. In general, the storage of raw material for items such as chili, onion and include spice category. The cooking process produced if the customers have ordered the food menu. The key informers explain that the reason was to keep the flavor and aroma of the dishes served. The activities in the kitchen who managed, by chefs that including the relative of the business owner. The next stage was the food delivery activity. The food delivery conducted the waitress and to make the food interesting the food delivered to the ancient container. It is to show the impression of the food culture concept

\subsubsection{Key Partnership}

The business of the restaurant has to the alliances with the various parties. Osterwalder \& Pigneur (2010) argue that there was some reason which drives the business partnership, such as (1) to optimize the allocation of resources and the business activity. (2) To reduce the risk in the competitive rivalry that had the uncertainty characteristics. (3) The company has its resources and to implement the business activity by the restaurant business model.The traditional restaurant admits that was very complex to operate the business activities without the partnership such as with the suppliers, government officials, and community.The key informers were also explaining that they should keep the supply of raw materials from suppliers, and they have to cooperate with the community in this area.Therefore, the approach was not only from the business aspect but the local culture value also.The partnership with fishers, suppliers and traders have the positive impact on the business relations was be closely. For instance, the partners invite to the workers of the traditional restaurant to attend the family events. This kinship has the positive impact on the business. In addition, to keep and guarantee of the supply, the purchase price has also become more stable than market prices. Furthermore, the partnership with the community intends to protect the natural source in this area such as the community did not catch and purchase the crabs spawn. The key informers recognize that the community attended to the business activities of the restaurant. Likewise, the community will lead the visitors who do not know the restaurant location. The partnerships with government personnel have the positive impact on the traditional restaurant. Nowadays, the traditional restaurant as a culinary tourism destination in a little town "Tanjung Pura."

\subsubsection{Cost Structures}

The traditional restaurant has the business principles to reduce the costs, therefore that the price expected by customers that could be reached. The key informers recognize that the restaurant had the goals to minimize costs, for example save energy and reduce transportation costs. The principle is in line with Osterwalder \& Pigneur (2010) explain that the business model focus to reduce the costs as low as possible, which has the value costs-driven. The business model aims to keep sustaining the value proposition. Moreover, the principle of value-driven to operate the business restaurant to retain the values of the food menu. Although, the materials price is higher than earlier, and the traditional restaurant always 
retains the quality of raw materials.

\subsection{TOWS Analysis}

Table 1. Summary of TOWS Analysis

\begin{tabular}{|c|c|c|c|c|}
\hline Elements & Threats & Opportunities & Weakness & Strengths \\
\hline $\begin{array}{l}\text { Customer } \\
\text { Segment }\end{array}$ & $\begin{array}{l}\text { - The emergence of a new } \\
\text { competitor. } \\
\text { - Many culinary businesses } \\
\text { in Tanjung Pura } \\
\text { - Loss of customers who } \\
\text { switch to the competitor } \\
\text { - Changes in publics trend } \\
\text { The competitors have a } \\
\text { better value proposition } \\
\text { include restaurant } \\
\text { atmospheres, high taste, } \\
\text { celationship with more } \\
\text { and better price. } \\
\text { manage the customer } \\
\text { delivered through the } \\
\text { attractive the consumers }\end{array}$ & $\begin{array}{l}\text { - The company has } \\
\text { benefited from the growth } \\
\text { of the food business } \\
\text { - The traditional restaurant } \\
\text { as a pioneer and became a } \\
\text { destination for domestic } \\
\text { travelers. } \\
\text { The traditional restaurant } \\
\text { has an opportunity to add } \\
\text { the various of value } \\
\text { proposition }\end{array}$ & $\begin{array}{l}\text { - Customers who harbored } \\
\text { in Tanjung Pura and } \\
\text { derived from outside of } \\
\text { Tanjung Pura } \\
\text { - The traditional restaurant } \\
\text { still not completing the } \\
\text { value proposition for } \\
\text { instance, in selecting a } \\
\text { strategic location and } \\
\text { provide children's } \\
\text { - Conducted for all visitors } \\
\text { playground area } \\
\text { commuitress still less }\end{array}$ & $\begin{array}{l}\text { - The value proposition of } \\
\text { traditional food that is the } \\
\text { menu-specific, species of } \\
\text { fish and shrimps distinctive } \\
\text { and fresh. } \\
\text { - There is a natural } \\
\text { atmosphere in-store and } \\
\text { out-store of the restaurant } \\
\text { - The effectiveness of existing } \\
\text { channel has the impact of } \\
\text { increasing the number of } \\
\text { visitors. }\end{array}$ \\
\hline Revenue Streams & $\begin{array}{l}\text { - The competitors use both } \\
\text { types of transactions that } \\
\text { matter is transaction } \\
\text { revenue and recurring } \\
\text { revenue. }\end{array}$ & $\begin{array}{l}\text { Traditional restaurant may } \\
\text { obtain another revenue } \\
\text { with membership system } \\
\text { (subscription fee), and } \\
\text { offer the advertising space } \\
\text { for vendor, banking, travel }\end{array}$ & $\begin{array}{l}\text { - Revenues only obtained } \\
\text { from "usage fee." } \\
\text { - Increasing the purchase } \\
\text { price of raw materials } \\
\text { can be reduced the profit } \\
\text { level }\end{array}$ & $\begin{array}{l}\text { Shown from earning } \\
\text { revenue stream and } \\
\text { continue to prioritize cash } \\
\text { in hand }\end{array}$ \\
\hline
\end{tabular}




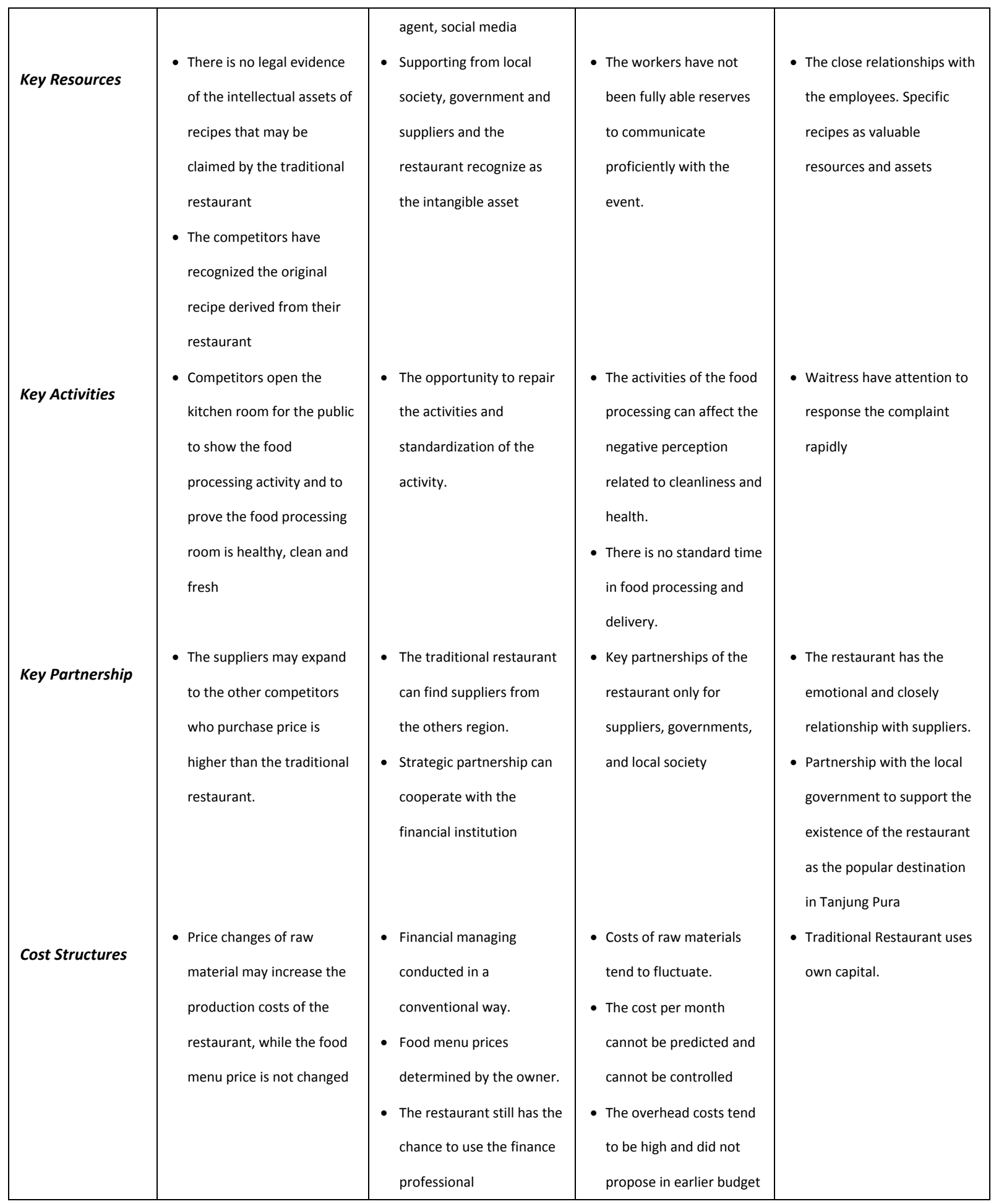

\subsection{Evaluation of Business Model Canvas}

Based on the explanation of Business Model Canvas on the traditional restaurant and TOWS result analysis, then the authors have obtained the new business model for improvement as follows: 
Table 2. New Business Model Canvas "Traditional restaurant."

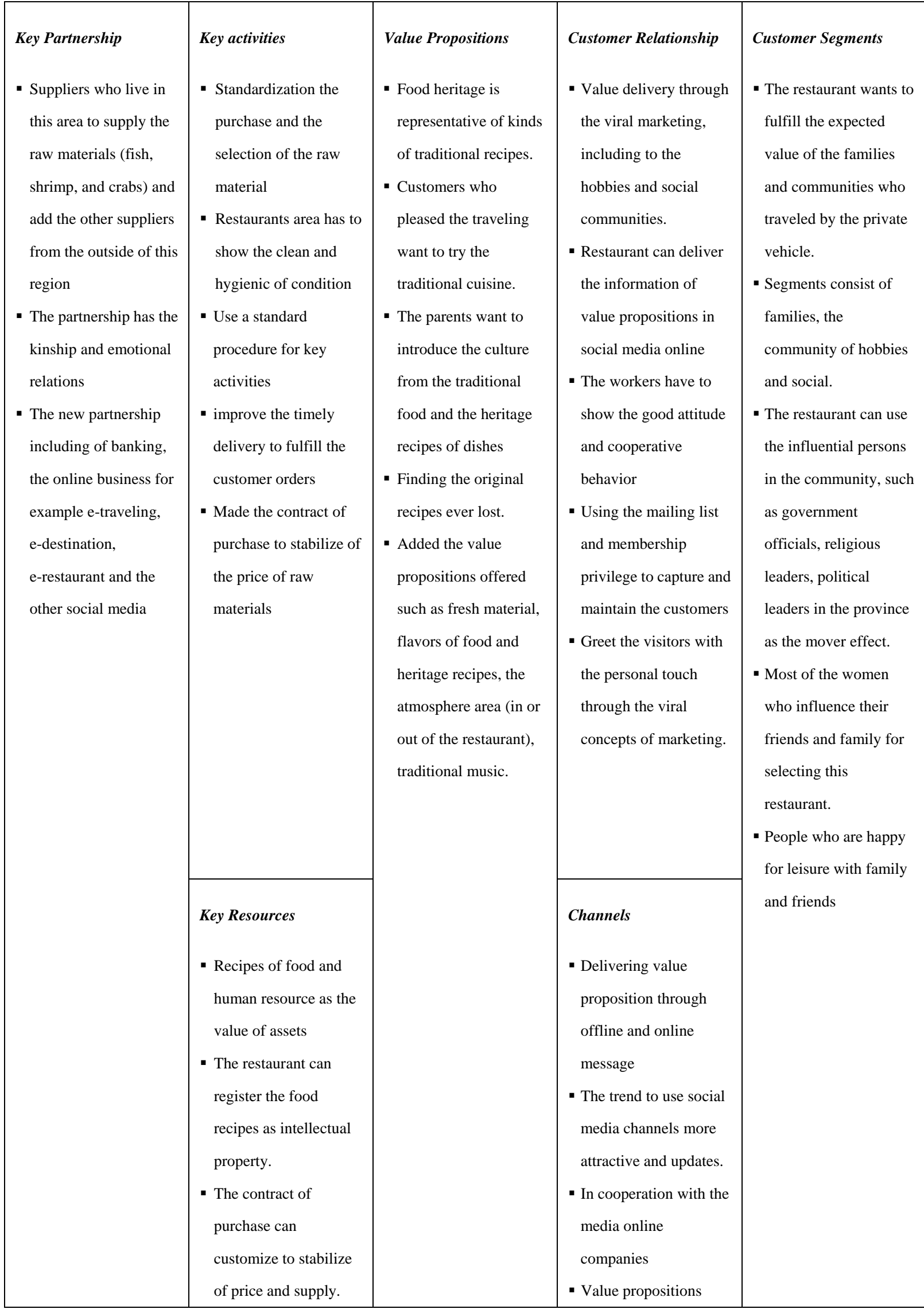




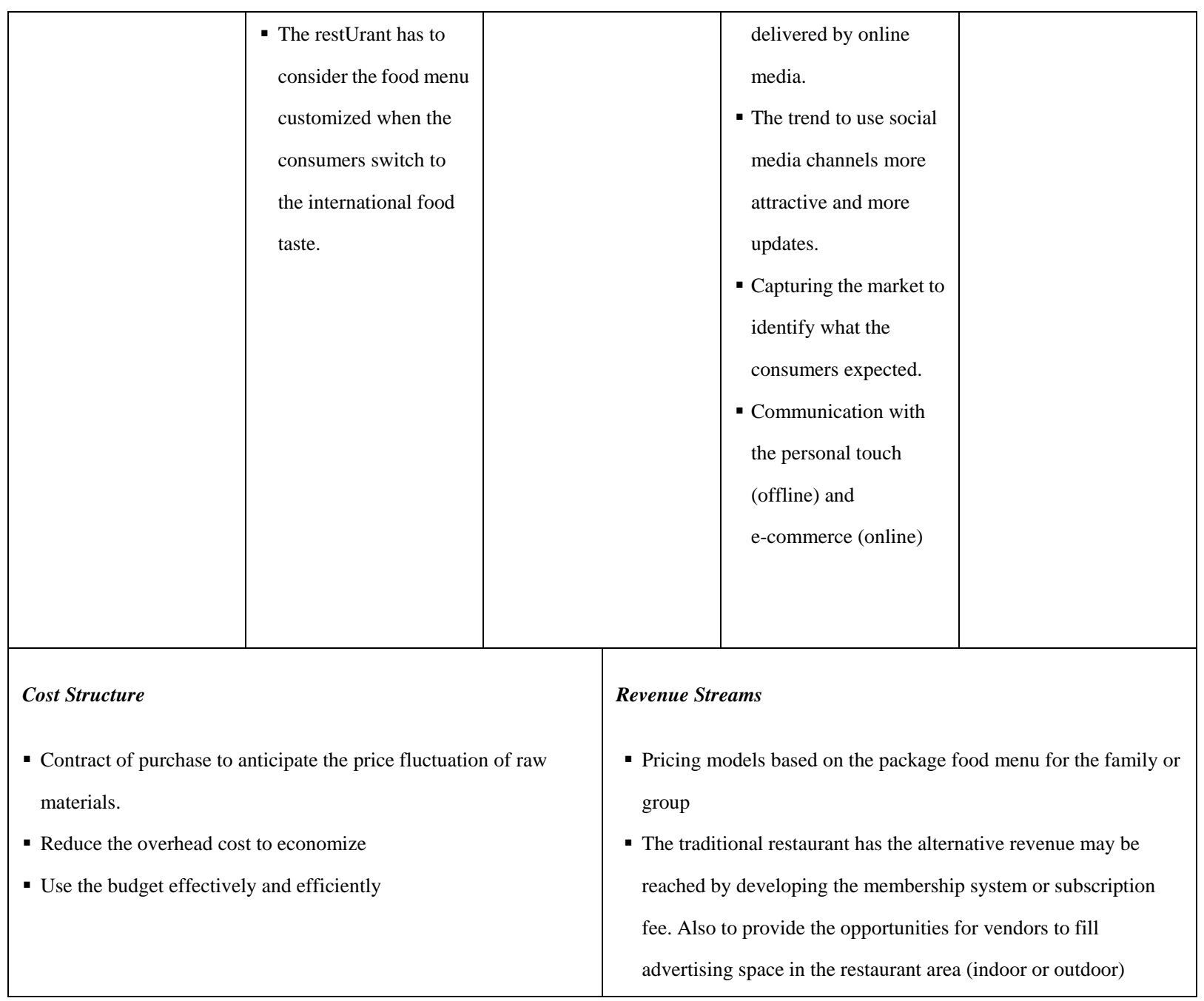

\section{Conclusion}

Conclusion of business model that has been running in traditional restaurant based on BMC as follows:

\subsection{Customer Segments}

The traditional restaurant has customer segments from family and community who enjoy traveling and crossing in Tanjung Pura. Various of customer segments included in the segmented, which is geared to serve customers who classified based on their needs. Typically, the travelers will stop to enjoy the special food dishes in Tanjung Pura; it is due to the recipes "Melayu" that inherited from ancestors.

\subsection{Value Propositions}

The traditional restaurant offers the atmosphere of the natural restaurant nuance, the scenery of the fishers small ship would be fishing. It remembers the memories, and attracted by the people who did not find in larger cities. Another value proposition delivered from the sources of the fishes, shrimps, and crabs in which originated from the fisheries catch. Unfortunately, the value propositions of the sources may replicate from the competitors. Indeed, the 
experience to enjoy the dishes including the value proposition offered. However, it also might offer from competitors. Besides that, one of the value propositions was the taste of specific food with typical recipes "Melayu." The traditional restaurant also provides specific fish called the fish "Sembilang." The food called "Gulai Asam" is also the favorite food that often the customers were searching. Moreover, the traditional restaurant puts the food dish with the old containers. The other value is local music, namely "Melayu Deli."

\subsection{Channels}

The traditional restaurant has channeled information originated from the visitors' families and friends. The friendliness of the manager attitude who always welcomes at the entrance to the restaurant. Likewise, the waitress had the treat with polite and friendly to the visitors. Hence, the traditional restaurant delivering the value conducted directly by the workers.

\subsection{Customer Relationship}

The traditional restaurant has close relationships with customers through customer acquisition, by relying on the role of a waiter at the time of serving the visitors. The waitress was friendly treatment can give a positive impression to the visitors so that they experience a visit to this restaurant may be delivered to consumers who had never come to this restaurant. Besides, by showing the attitude and actions proactively notify customers when they visit the traditional restaurant. Traditional restaurant business always asks the opinion of the visitors, a specific menu of what they expect as the restaurant attempts to create a new proposition that is ready to be offered to the visitors in the future

\subsection{Revenue Streams}

The traditional restaurant relies on income with the cash payment of transactions by visitors. Sources of primary income of the traditional restaurant only originated from the revenues generated by the food menu transactions. How many foods menu the order from the visitors. Another income derived from the event of company particular or the business community

\subsection{Key Resources}

The traditional restaurant has assets in the form of buildings and vehicles. Nevertheless, the informers assume the tangible assets have a lower value than the intangible asset. In the traditional restaurant, the recipes have a higher value than the others. It assumed the recipes as intellectual assets. Another asset value as waitress, chefs, cashiers and workers who involved in the restaurant activities, thus the assets has the leverage to enhance the value of the business.

\subsection{Key Activities}

The traditional restaurant has the particular activity; start from the purchase of raw materials such as fishes, crabs, and shrimp. Moreover, to purchase of spices in enhancing the flavor of the foods. The next activity is the selection process and storage. The processing of raw materials in the kitchen room that conducted by some experienced chefs. Then, the next 
activity is delivery the order by the waitress.

\subsection{Key Partnership}

The traditional restaurant recognizes that is tough to carry out the business activities without the partnership with suppliers such as fishers, agents, and traders. The partnership with community intends to preserve the safety of the environment in around of the restaurant. Moreover, the partnership related to government personnel that had the positive impact on the culinary destination in the little town of Tanjung Pura.

\subsection{Cost Structure}

Conducting the business principle of the traditional restaurant is how to reduce the costs become efficient. The traditional restaurant is aware that the price of food menu has to customize with the customer's expectations. The traditional restaurant way is to decrease the costs of transportation and energy use. Nonetheless, the traditional restaurant did not reduce the quality of raw materials to minimize the costs when the raw material price to be high. It showed the restaurant remains to prioritize on customer satisfaction.

\section{Acknowledgements}

The authors gratefully acknowledge the financial support from the University of Pembangunan Pancabudi and We thank the editor and double blind peer reviewers for their constructive comments, which helped us to improve the manuscript.

\section{References}

Baden-Fuller, C., \& Morgan, M. S. (2010). Business models as models. Long range planning, 43(2), 156-171. http://dx.doi.org/10.1016/j.lrp.2010.02.005

Chesbrough, H. (2013). Open business models: How to thrive in the new innovation landscape. Harvard Business Press.

Chesbrough, H., \& Rosenbloom, R. S. (2002). The role of the business model in capturing value from innovation: evidence from Xerox Corporation's technology spin-off companies. Industrial and corporate change, 11(3), 529-555. http://dx.doi.org/10.1093/icc/11.3.529

Coes, D. H. (2014). Critically assessing the strengths and limitations of the Business Model Canvas.

David, Fred R. (2004). Strategic management : cases . Edition:10th ed: Prentice Hall

Levy, M. (2001). The Principles of Highly Successful Business Models: Using the Value Framework $^{\mathrm{TM}}$ ECnow, Inc.

Mitchell, D. W., \& Bruckner Coles, C. (2004). Business model innovation breakthrough moves. Journal of business strategy, 25(1), 16-26. http://dx.doi.org/10.1108/02756660410515976 


\section{Macrothink}

Business Management and Strategy

ISSN 2157-6068

2016, Vol. 7, No. 2

Morris, M., Schindehutte, M., \& Allen, J. (2005). The entrepreneur's business model: toward a unified perspective. Journal of business research, 58(6), 726-735. http://dx.doi.org/10.1016/j.jbusres.2003.11.001

Osterwalder, A., Pigneur, Y. (2010). Business model generation: a handbook for visionaries, game changers, and challengers. New Jersey: John Wiley \& Sons, Inc.

Osterwalder, A., Pigneur, Y., \& Tucci, C. L. (2005). Clarifying business models: Origins, present, and future of the concept. Communications of the association for Information Systems, 16(1), 1 .

Teece, D. J. (2010). Business models, business strategy and innovation. Long range planning, 43(2), 172-194. http://dx.doi.org/10.1016/j.lrp.2009.07.003

\section{Copyright Disclaimer}

Copyright for this article is retained by the author(s), with first publication rights granted to the journal.

This is an open-access article distributed under the terms and conditions of the Creative Commons Attribution license (http://creativecommons.org/licenses/by/3.0/). 